INDEPENDENT JOURNAL OF MANAGEMENT \& PRODUCTION (IJM\&P)

http://www.ijmp.jor.br

v. 12, n. 1, January-February 2021

ISSN: 2236-269X

DOI: 10.14807/ijmp.v12i1.1237

\title{
THE IMPACT OF CEO'S PERSONAL CHARACTERISTICS ON CORPORATE SOCIAL RESPONSIBILITY: EVIDENCE FROM \\ BANGLADESH
}

\begin{abstract}
Mir Md Nazrul Islam
School of Accounting Zhongnan University of Economics \& Law, China

E-mail: mirtuhin422@gmail.com
\end{abstract}

Dejun $W u$

School of Accounting Zhongnan University of Economics \& Law, China

E-mail:djwu2005@164.com

Muhammad Usman

Department of Economics \& Business Administration University of

Education, Lahore (Faisalabad Campus), Pakistan

E-mail:m.usman@ue.edu.pk

Muhammad Imran Nazir School of Finance Zhongnan University of Economics \& Law, China

E-mail: imran.n13@outlook.com

Submission: $1 / 5 / 2020$

Revision: $2 / 14 / 2020$

Accept: 2/25/2020

\section{ABSTRACT}

Purpose: Advanced CSR research is still in the context of developed countries. Very limited research is available in the CSR system of developing countries such as Bangladesh. Specifically, this paper examines the impact of CEOs personal characteristics on CSR among the public listed company in Bangladesh.

Theoretical Framework: This study also focuses on six firm characteristics firm size, profitability board size, firm leverage, sales and cash.

Design/Methodology/Approach: Using ordinary least square (OLS) regression analysis on 100 public listed firms at Dhaka stock exchange (DSE) and Chittagong stock exchange (CSE) in Bangladesh.

Originality/Value: this study provides new evidence on the relationship between CEO Characteristics and corporate social responsibility in Bangladesh. 
DOI: 10.14807/ijmp.v12i1.1237

Findings: The results show that CEO's impressive positive and rationally significant, which means male is better than women, corporate strategy is better than women in their strategy. One of the most important reasons for education because education also results CEO business education positive and significant, which ultimately affects the organization. The Chief Executive Officer of the organization is an important part of religion and its religion, so that the religion of CEO is Islam and Christian, then he will have more impact on the social welfare organization. The variability of CEO's religion (Islam and Christian) is positive, which affects the company's social welfare, which ultimately increases the company's value.

Keywords: CEOs Personal Characteristics; Corporate Donation; Corporate Social Responsibility; Public Listed Firms, Bangladesh

JEL Classifications: M14, L20, Q01.

\section{INTRODUCTION}

Business organization grow in society and by law, it also has been given the identity of a legal individual in almost all over the world. As a legal identity, the business organization operated its activities in society and with humans and held responsible for its operations as well as. It is now becoming a general perception that business will contribute not only through employment but also through some other responsibility without expecting a profit. Though these activities are done without expecting profit, it is assumed that these have an impact on profit and goodwill of companies.

In previous, it was believed that corporate social responsibility is a western phenomenon, but now it has reached too many developing countries in Bangladesh as standards of business are more developed. Companies are willing to uphold their social involvement, ethical scale, economics contribution, and so on. In a business sense for a business, it has divergent practices and initiatives and is supported by communications, marketing, community involvement and sustainability. It also needs to be very transparent because these policies embrace the social responsibility of organizations to their stakeholders, employees, environment, economy, shareholders, customers, suppliers, community involvement and other legal frameworks.

Although CSR has many businesses that do not even implement anything, it is arguable that companies should not only make a profit from society but also perform specific duties. So, it has become a big question of why there are such companies and some do not. If there are ethical considerations and social involvement, what are the reasons for companies that do not 
INDEPENDENT JOURNAL OF MANAGEMENT \& PRODUCTION (IJM\&P)

http://www.ijmp.jor.br

v. 12, n. 1, January-February 2021

ISSN: 2236-269X

DOI: 10.14807/ijmp.v12i1.1237

have a corporate social responsibility? With this question, it is as complicated as the related variables, such as education, age, religion, and so on.

These facts are studied in this paper. Every consideration powerfully recommends that the CEO is especially pertinent in company CSR decisions and that CSR plays an essential role in many companies leading role in applying corporate social responsibility (CSR) activities. Corporate social responsibility (CSR) isn’t a zero-sum game among business \& society. Going as well as compliance and creating standard value are essential to any firms CSR activity (Porter and Kramer (2006); Waldman et al. (2006a), (2006b)).

Further, acknowledging that the performance of the companies provides a gap in accounting literature for decision making on the Board of Directors' capabilities, which requires further explanation (Alshareef \& Sandhu, 2015). Studies have also proposed that corporate donations by the organization due to financial benefits. Positive attributes as high profits and low impact may affect their decision to make corporate donations. Besides, firm size can give corporate gifts (Ali et al., 2009).

Whereas, building on the upper echelon principle, several earlier studies document that CSR approaches lead to the inherent decisions of the Chief Executive Officer (CEO) and are especially decided by their capacity (Chatjuthamard et al., 2016; Yuan et al., 2017). This is because CSR investment has a long-term economic impact, being strongly conditioned by the CEO's professional opportunities that derive from his or her ability (Yuan et al., 2017). In this context, better corporate results are obtained by the ablest CEOs which turn into increases within their remuneration or the likelihood of being signed by other companies (Ali, Li, \& Zhang, 2015).

Because executives are directly involved in formulating CSR strategies (Waldman, Siegel, \& Javidan, 2006), a burgeoning research stream based on the upper echelons (UE) perspective (Hambrick \& Mason, 1984) suggests that the huge variance in CSR reflects heterogeneity in the motives of corporate leaders (Petrenko et al., 2016; Wowak et al., 2016).

Besides, there is empirical evidence that the CEO is a significant decision shaper in CSR related judgment. For example, according to by Waldman et al. (2006), Anita Roddick, CEO. Since 2008 the CR Magazine (Corporate Responsibility Magazine) subsidization the most ethical responsible CEO's in the US and other developing countries on the stage to which they put themselves at personal and business risk to convey on corporate responsibility expectation, thus acknowledge CEO’s leading role in addressing CSR activities. 
This study makes significant contributions to field knowledge in different fields the way. This includes the gap in literature, and the gifts included in the theory and address of additional insights for some outstanding general contributions. The findings of this study mainly contribute to the impact of the CEO's personal characteristic on corporate social responsibility.

Regarding the theory, this study has proposed a new dependent variable by corporate donation on the influence of the CEO's activities on corporate social responsibility. It can help to understand the CSR activities of a firm what's the impact between the CEO and CSR. This study also focuses on which element of the Chief executive officer are more influenced for CSR activities.

According to Bangladesh, the previous writer discusses corporate social responsibility in Bangladesh but we try to find why they donate more for corporate social responsibility. This can help to understand the process behind the implementation of the CSR and know what is needed before implementing the relevant CSR techniques also the effect of CEO's activities. This study is highlighting the minimalism of the impact of the contribution CEO features on CSR studies to test the impact of CEO characteristics of CSR through our regression's method.

The remainder of this study is organized as follows: Section 2 explains the literature review related to corporate social responsibility and CEOs personal characteristics on firms. Section 3 explains the data set, model specification, and variable descriptions. Chapter 4 describe the descriptive statistics, Correlation matrix and then our regression estimation results. 5 gives the conclusion and policy recommendations.

\section{LITERATURE REVIEW AND HYPOTHESIS DEVELOPMENT}

\subsection{Determinants of Corporate Social Responsibility (CSR)}

Corporate Social Responsibility can be described as a voluntary commitment to business organizations to contribute to social and environmental goals. The modern society represents businesses with very complex problems that it was not previously (Davis, 1975). There is no doubt that it is respectful to society's moral values for the existence and survival of a social unit and organization in the business. The Society is curious to know about business activities. Increasing popularity of 'social welfare' is also compelling business for performing some social responsibility. That is why the idea of 'Corporate Social Responsibility (CSR)' is a burning question in today's world. 
DOI: 10.14807/ijmp.v12i1.1237

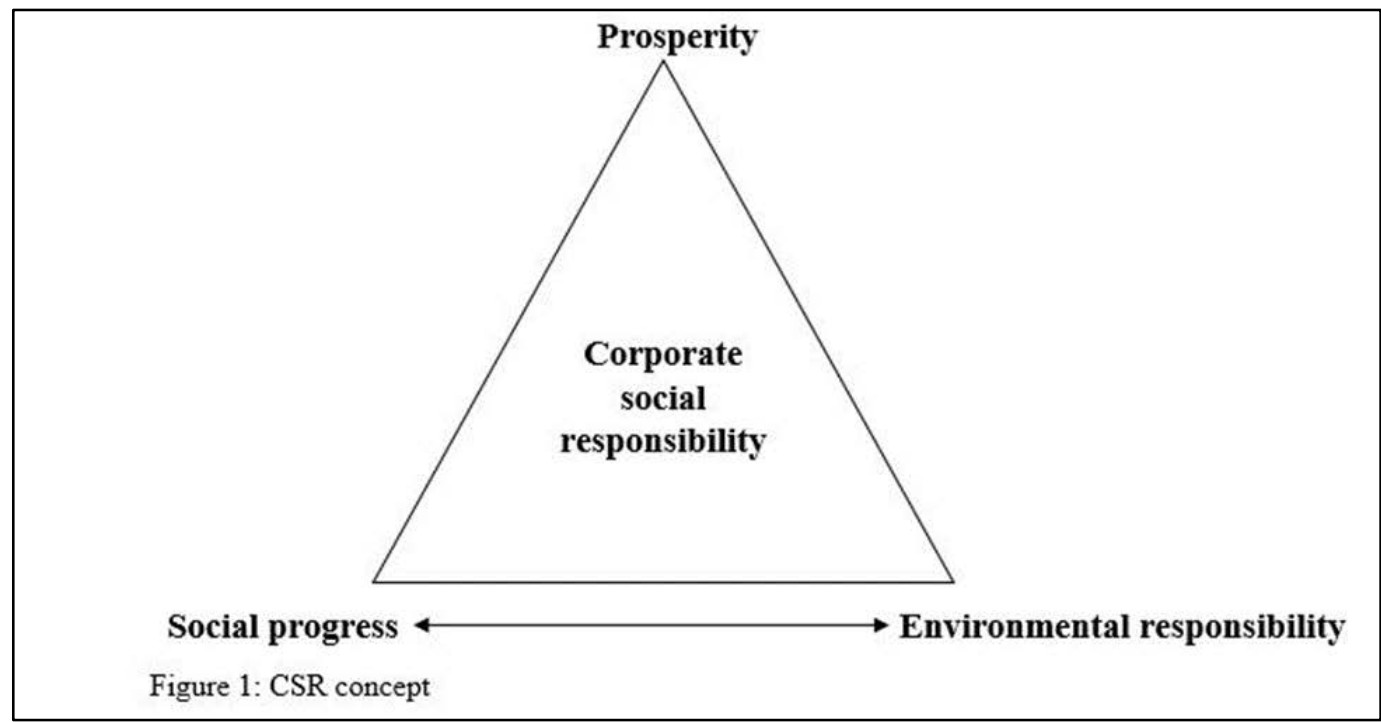

Figure 1: CSR concept

The CSR concept refers to the creation of economic prosperity, environmental quality and social progress and matrices, which help in measuring the activities of a company not only in the economic, social and environmental field. Corporate social responsibility is generally defined by a concept by which companies Managing their business and featuring social and environmental concerns among them Interaction with their stakeholders on an individual basis "(European Commission, 2001:8).

In regards to human rights, labor, environment and corruption-related corruption, the United Nation's Global Compact Ten Principles can be used to provide a solid ground for a modern definition of CSR. These policies enjoy universal consensus and initially originated from the United Nations Convention on the Universal Declaration of Human Rights, the declaration of the International Labor Organization, the Fundamental Principles and the Right to Work, Rio Declaration on Environment and Development. Global Compact In their area of influence, the following fields (United Nations Global Compact Office, 2008) want to embrace, support and form a set of the following fundamental values:

Table 1: The United Nation's Global Compact Ten Principles

\begin{tabular}{|l|l|}
\hline \multicolumn{1}{|c|}{ Sources } & \multicolumn{1}{c|}{ Principle } \\
\hline Human right & $\begin{array}{l}\text { Principle 1: Businesses should support and respect the protection of } \\
\text { internationally proclaimed human rights. } \\
\text { Principle 2: Make sure that they are not complicit in human rights abuses. }\end{array}$ \\
\hline Labor Standards & $\begin{array}{l}\text { Principle 3: Businesses should uphold the freedom of association and the } \\
\text { effective recognition of the right to collective bargaining; } \\
\text { Principle 4: The elimination of all forms of forced and } \\
\text { compulsory labour; and } \\
\text { Principle 5: The effective abolition of child labour; }\end{array}$ \\
\hline
\end{tabular}


ISSN: 2236-269X

DOI: 10.14807/ijmp.v12i1.1237

\begin{tabular}{|l|l|}
\hline The Environment & $\begin{array}{l}\text { Principle 7: Businesses should support a precautionary approach to envi } \\
\text { ronmental challenges; } \\
\text { Principle 8: Undertake initiatives to promote greater environmental resp } \\
\text { onsibility; and } \\
\text { Principle 9: Encourage the development and diffusion of } \\
\text { Environmentally friendly technologies. } \\
\text { Principle 6: The elimination of discrimination in respect of } \\
\text { employment and occupation }\end{array}$ \\
\hline Anticorruption & $\begin{array}{l}\text { Principle 10: Businesses should work against corruption in all its forms, } \\
\text { including extortion and bribery. }\end{array}$ \\
\hline
\end{tabular}

Source: United Nations Global Compact Office, (2008).

Often Phillip Kotler defines CSR. In his view, "committed to consolidating CSR community - disorderly business practices and contribution of corporate assets" (Kotler \& Lee, 2005). One of the main components of this definition is conscience which talks about a voluntary commitment that contributes and contributes. "Corporate Social Enterprises are the main activities operated by a corporation to support the social work and fulfil the promise of corporate social responsibility" (Kotler \& Lee, 2005). Causes may be supported by this initiative: a) Health, safety, education and employment, b) Environment, c) Community and economic development and other essential humanitarian needs.

According to Carroll and Brown (2018), "each of the words for which CSR stands" can define corporate social responsibility (CSR). Corporate refers to all types of companies, including large, medium and small enterprises. A study by Wan et al., (2008) shows that awareness of CSR of the listed company has had a positive effect on corporate refinancing control.

Loi, Lam and Chan, (2012) Believe that the excellent performance belt of the social responsibility of the intermediate industry can reduce the enterprise project limitation, reduce initiative barriers, and increase the corporate image and social awareness. Corporate responsibility is not an honest attempt but tends to depend upon visual aspect and position (Campbell, 2007; Matten \& Moon, 2008). The International Finance Corporation (CSC) "CSR promises good for business and the development of sustainable economic development by working with staff, their families, local communities and society for better development of their lifestyle" (IFC, 2008).

\subsection{The Effects of CEOs Characteristics on firms}

CEO is the key decision-maker of the company and is responsible for the formulation and implementation of corporate strategy related to corporate social responsibility. Therefore, the characteristics of the CEO will inevitably affect the performance of corporate social 
DOI: 10.14807/ijmp.v12i1.1237

responsibility. From the current research literature, compare the relationship between social responsibility and enterprise of enterprise value of the literature, but the study of CEO characteristics on the impact of corporate social responsibility literature is less, this paper attempts to study the influence of CEO on education, term of compensation and stock characteristics of corporate social responsibility, to contribute to the understanding of CEO features in the role of CSR.

The CEO's particular manager focuses on the stakeholders, depending on the market manager's pricing and policies. Hambrick and Megan (1984) "High Voluntary Theory", that, the mental structure of cognitive skills, the perceived power and values of the top management team, determines the process of taking strategic decision-making and related performance. However, the mental structure of the senior management team is difficult to measure in actual research accurately, and other associated features such as age, educational background, religion and other objectives of the leading management team are closely associated with managers cognitive skills and standards.

The nature and uncertainty of assessing the psychological aspects of CEOs was recognized by Hambrik and Mason (1984). The writers have concluded that more realistic and tangible can be the visible demographic markers of managers that apply to their personalities such as education level, business degree, age, class, ethnicity and duration of tenure (Abdullah \& Said, 2018).

Despite their opposition to the duty of executives, both the opinion of creditors and the view of lenders are of a normative sort (Donaldson \& Preston, 1995): they stipulate what executives should do. We do not, at the same time, compensate for what the managers want to do. Yet a the array of research shows that there is a considerable variation in the motivations of managers to adhere to the interests of clients and/or customers (Gupta, Briscoe \& Hambrick, 2017; Kang, 2016; Tang et al., 2015; Wowak et al., 2016).

This paper is mainly from the CEO's characteristics, to pay attention to its responsibilities on social responsibility, and shareholders of these aspects. (1) Chief Executive Officer and CSR the Social Responsibility Program has been considered as an investment, which can increase the enterprise value over the long term, and CEO's reputation can be increased by attracting media attention. The CEO's educational level determines the CEO in some degree, with few knowledge-based enterprises have higher responsibilities in legal 
DOI: 10.14807/ijmp.v12i1.1237

responsibilities, charitable responsibilities and economic liabilities, and there is a significant difference between them and social responsibility will be okay.

A characteristic is a feature that assists in differentiating a person or happening. An aspect can be theoretical to emotions, attitudes, behavior, and attribute. Furthermore, a characteristic can also characterize the physical, demographic, and interpersonal feature of a CEO. The following writing gives information on CEO characteristics.

Table 2: CEOs characteristics, categories and examples:

\begin{tabular}{|c|l|}
\hline TYPES OF CHARACTERISTICS & EXAMPLE OF CHARACTERISTICS \\
\hline Education & Which field of study, MBA or Others Education \\
\hline Religion & $\begin{array}{l}\text { Which religion belongs, Islam, Hindu, Christian, } \\
\text { Buddhism, or no religion. }\end{array}$ \\
\hline Age & Young or Old \\
\hline
\end{tabular}

More assessments of symptoms: example

- Personality (personal, social and moral characteristics)

- Background (the social-demographic background of the CEO)

- Experience (education, professional and personal experience)

- External Elements (Places lived country, married or single, having children or not

- Internal Elements (Political side, willing to donate for charity).

\subsection{CEO age and Corporate Social Responsibility}

CEO's intellectual capabilities such as knowledge, experience, skills, educational level achievements can be enhanced when his or her age rises (Sitthipongpanich \& Polsiri, 2015). Based on upper echelon theory, it has been documented that CEO age has an impact on the level of corporate social success in industry (Lee et al., 2018; McCarthy et al., 2017). There is a difference between young and old managers in the career concerns of the CEOs according to Fabrizi et al. (2014). The authors argued that since young managers have to deliver positive, observable results to the market, they tend to take actions that focus on observable short-term outcomes and are less likely to boost field activities related to social / environment.

Like young executives, older CEOs are not under high market competition than younger colleagues and older executives have a greater reason to be involved about corporate social success (Fabrizi et al., 2014). Shahab and Chen (2019), who pointed out that young CEOs are more eager to pursue profit maximization, leading to a decrease in sustainable activities and performance, are supporting that view. In contrast, the author found that, are willing to develop new products and risk the original investment. On the other hand, from long-term career 
DOI: 10.14807/ijmp.v12i1.1237

anxiety, young or newly appointed CEOs behave more carefully because they struggle to keep their positions and build their own for the future. Young CEO's are a far-visioning businessman with a new perspective to reshaping the future business environment and are more willing to adopt corporate social responsibility.

\section{- H1: Young CEO's are more willing to adopt corporate social responsibilities.}

\subsection{CEO of Education and Corporate social responsibility}

More educated CEO's are intended to foster corporate social responsibilities rather than others. CEO educational specialization is positively associated with consistency in firm CSR performance. Top manager's education level there has been a lot of research topics. Two studies have shown that more educated Excessive cognitive complexity (Hitt And Tyler 1991). It is generally assumed that such cognitive complications give more exceptional ability to absorb new ideas and therefore increase the tendency toward adoption.

Hambrick and Megan (1984) say that education can aid as an index of a person's standard and perceptive base because they think that most persons take their decision seriously about training. Following the view of high civilization, CEO's education will have an implicit impact on the CSR report that is through its perception of environment-related. For example, various authors have noticed that with higher education, crucial strategic decision-makers have invested in critical asset allocation decisions such as innovation or diversification.

Datta, Rajagopalan and Zhang (2003) for example, especially that the CEO is the perfect material for change in educational background and is available in conjunction with this strategic firmly negatively related (similar construction committed as a condition). According to "There is a liberal outlook for directors with higher education, which can lead their organization to a more social position" (Quazi, 2003:824).

However, established on meta-analysis executed by Borkowski and Ugras (1998), the educational background of a person with no effect. Also, Zu and Song (2009), who instead of classifying the person according to their degree, measured the director's education by the number of years, CSR did not have a significant impact on every person's perspective. Scholars have already looked into the correlation regarding the field of study of CEOs and their tendency to pursue CSR strategy (Manner, 2010).

Most of the past researches have agreed that economics graduates will not be able to follow the CSR method, who are graduates of Humanities or Social Sciences (Frank \& Schlutz, 
DOI: 10.14807/ijmp.v12i1.1237

2000; Manor, 2010). On the contrary, a postgraduate CEO in human or social science department can take good initiative about social impact and observe environmental standards (Rivera \& De Leon, 2005).

According to the implications of undertaking an MBA, various conception exists (Manner, 2010). It is mainly due to the fact that MBA programs are developed and more corporate social performance and profit maximization (Jones, 1995; Kuhn, 1998) considers the interests of other stakeholders. One of the main concepts that emphasized is a role in which a CEO is to play in a firm strategy - in large quantities - possible events on their consideration level in particular, Hambrick (2007) proposed that the CEO is a greater level than a discreet, higher organization estimates are more effective.

\section{- H2: Education influences the decision of adopting corporate social responsibility.}

\subsection{CEO of Religion and Corporate social responsibility}

Throughout history, religion has played a critical role in changing the way humanity has progressed. Every major civilization has at its heart, inspiration from a spiritual source. Religious people are pious and tend to fulfil the responsibility to society from the perspective of their religion. Several studies also inspect and found confirmation for the influence of religiousness on an Entity's awareness on CSR.

Furthermore, the authors assumed that variation exists in the individuals' attitudes to aspects of CSR across religions. Their results indicate that religious individuals indeed appear to expect companies to be responsible to a greater extent than non-religious individuals, for some areas of responsibility. Throughout the past, religion has played a vital role in effecting the way humanity has upgraded. Managerial CSR Opinion and Forecasting (recently reported and related research related Graflend et al. (2007) research on the impact and impact of personal values, (Bramer et al. 2005). The idea of this writing has the effect of religious importance on socialist socialism (Bramer et al. 2005).

Epstein (2002) and Calkins (2000) state that religious belief can work incompatibility with human reason to engage the idealistic of love and consciousness to others. In this way, religion dictates the actions of the people and bring specific results. They concluded that Angelidis and Ibrahim (2004) found no difference between religious and non-people, although Weaver and Edge (2002) found a negative relationship between religious and traditional behavior. Grafleland et al. (2007) found that among religious people, socially responsible behavior may be different (for example, monotheist and who forever). 
DOI: 10.14807/ijmp.v12i1.1237

Table 3: The Golden Rule

\begin{tabular}{|l|l|c|}
\hline Religion name & \multicolumn{1}{|c|}{ The rule / regulation } & Source \\
\hline Islam & $\begin{array}{l}\text { No one of you is a believer until he desires for his brother that } \\
\text { which he wants for himself. }\end{array}$ & Sunnah \\
\hline Christian & $\begin{array}{l}\text { As ye would that men should do to you, do ye also to them } \\
\text { likewise. }\end{array}$ & Luke 6:31 \\
\hline Hindu & $\begin{array}{l}\text { This is the sum of all true righteousness: deal with others as } \\
\text { thou wouldst thyself be dealt by. Do nothing to thy neighbour } \\
\text { which thou wouldst not have him to do thee after. }\end{array}$ & The Mahabharata \\
\hline Buddhist & Hurt not others in ways that you would find hurtful. & Udana-Varga 5:18 \\
\hline
\end{tabular}

- H3: Religion does impact corporate social responsibility decision of CEO.

\section{MODEL AND METHODOLOGY}

This is an empirical study. The reason for the adopting and not adopting corporate social responsibilities will be compared in it. Along with those influential elements of the policy, decision will also be discussed by proving the hypothesis. The research followed constructive philosophy as it measures the experience of individuals in actions (Creswell, 2014). However, some numerical formation will be brought for a better extension of understanding. It will follow subjectivity strictly to prove the hypothesis and find answers to research questions (Maxwell, 2013).

The case-oriented strategy is adopted here as a specific organization will be evaluated. It will study the past of the companies then decide to select them with biased opinions (Yin, 2009). As an influential element of adopting corporate social responsibility is a significant concern of the study mono-method is being followed to understand human behavior in this case behavior of CEOs and to get the perspective that gives deep insights of experience and diversity (Yin, 2011).

\subsection{Data collection and Sample Selection}

Data were collected from two primary sources. First, we managed firm financial, operational data and substantial Donation amount from company annual report. Secondly, the CEO's data was collected from the company's annual reports, websites, Bloomberg and Wikipedia etc. These were mainly found on the net and firm yearly reports. To be able to observe differences from one CEO to another, the data collected year by year and firm by firm. To approach relevant data, the sample was the 100 listed companies of the Dhaka stock exchange and Chittagong stock exchange.

\subsection{Model}

I mention below model respectively Model 1 to Model 4. 
Model 1:

$C D=\alpha_{0}+\alpha_{1} C E O A G+\alpha_{2} F I R M S+\alpha_{3} B O A R D S+\alpha_{4} R O A+\alpha_{5} L E V+\alpha_{6} S A L+\alpha_{7} C A H+v_{i t}+u_{i t}$ Model 2:

$C D=\alpha_{0}+\alpha_{1} C E O E D+\alpha_{2}$ FIRMS $+\alpha_{3} B O A R D S+\alpha_{4} R O A+\alpha_{5} L E V+\alpha_{6} S A L+\alpha_{7} C A H+v_{i t}+u_{i t}$ Model 3:

$C D=\alpha_{0}+\alpha_{1} C E O E D B+\alpha_{2} F I R M S+\alpha_{3} B O A R D S+\alpha_{4} R O A+\alpha_{5} L E V+\alpha_{6} S A L+\alpha_{7} C A H+v_{i t}+u_{i t}$ Model 4:

$C D=\alpha_{0}+\alpha_{1} C E O R I+\alpha_{2}$ FIRMS $+\alpha_{3} B O A R D S+\alpha_{4} R O A+\alpha_{5} L E V+\alpha_{6} S A L+\alpha_{7} C A H+v_{i t}+u_{i t}$

In the above equation, CD means corporate donation as a proxy for corporate social responsibility. CEOAG denotes the CEOs age, which is our first independent variable. CEOED express as CEOs education and CEOEDB indicates CEOs education business. We have used two factors for educational background. CEORI shows CEOs religions which are also have used different factors. For the equation we have used same control variable which denotes, FIRMS, BOARDS, ROA, LEV, SAL, and CAH respectively Firm Size, Board Size, Return on Asset, Leverage, Sales, and Cash.

\subsection{Variable Measurement}

Our hypothesis, dependent, independent and control variables have to be verified. The following drawings describe how the variables are taken.

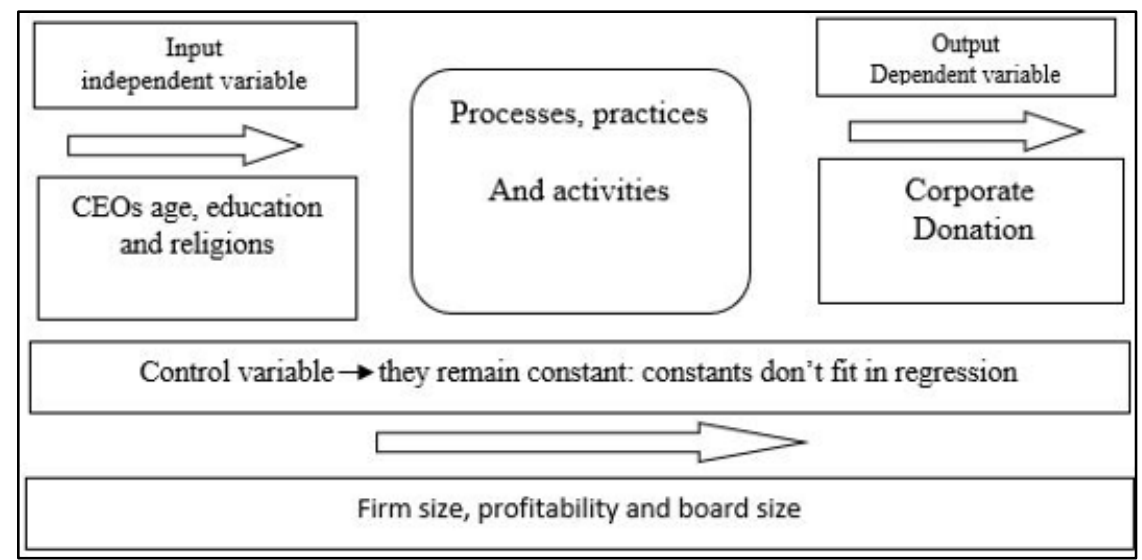

Figure 2: Dependent, independent and control variable

\subsubsection{Dependent Variable}

The dependable variable for our study is the corporate donation. We used as a proxy a corporate donation for CSR activities. Using information revealed by the corporation so proxy for CSR action as specified by Clarkson et al. (2008). This research focuses on donation. 
DOI: 10.14807/ijmp.v12i1.1237

Depending on the study of corporate donation variables in this study, firms check that they do not donate to corporations. If a corporation gives corporate, we took value. This study we used donation amount as a dependent variable. Bangladesh has the law for banking sector for CSR donation. It is compulsory for every bank. But there is no rule of law in other areas. This is a reflection of the company's reputation, which is the main reason for determining its ability to build long-term shareholders.

\subsubsection{Independent Variable}

\section{CEO's Age:}

The first independent variable is the CEO age. We included the CEO's maturity as an independent variable because the age of CEO's might influence them to donate CSR. Young CEO is willing to accept a visionary business person and corporate social responsibility with a new perspective to redefine future business environment. On the contrary, the authors realize that the CEO's age has had a positive impact under policies and social responsibilities, indicating that the role of morality and social responsibility of older people is less important. But a few authors also said that no effect about the CEO's age. There is some controversy about the CEO's age. In my study, we try to find what the impact of the CEO's age on CSR is.

\section{CEO's Education:}

The second independent variable is CEO education. This has been calculated with two different factors. The $1^{\text {st }}$ one is the CEO Business education background or business education. In this case, the dummy variable takes the value 1 for business education. In the other case, a CEO not business education background, the dummy variable takes the amount 0 . The $2^{\text {nd }}$ measure regarding the CEO education concern the CEO education level (masters or above).

For this measure, I created again dummy variable one is CEO education level (masters or above) or not qualify education level. In this case, the dummy variable takes the value 1 for qualify CEO education level. In the other case, a CEO does not qualify education level; the dummy variable takes the amount 0 . I chose this classification because data were quickly accessible are either business schools or postgraduate or above. This way, by looking at which school the CEO has undertaken, it is easy to determine their background.

\section{CEO's Religion:}

The third and last independent variable is CEO religion. Weaver and Eagle (2002) explain that a person who plays an essential role in a person's own life is different, because the 
DOI: 10.14807/ijmp.v12i1.1237

centre of recognition of soul may be of other religions. Bramer et al. (2005) estimated that members of religion could hold a broader understanding of the company's responsibilities. This has been calculated with four different factors. The $1^{\text {st }}$ one is the CEO's religion Islam. In that time, the dummy variable takes the value 1 . If the CEO's is not Islam, the dummy variable takes value 0 .

The 2nd measure concerning, the CEO's religion Christian I have used the dummy variable 1. On the other hand, CEO's religion is not Christian; the dummy variable uses the value 0 . Further The 3rd one is the CEO's religion Hinduism; we used the value 1 as dummy variable and the CEO's religion is not Hinduism. We used the value 0 . The $4^{\text {th }}$ one I create again dummy if CEO's no religion I take the value 1 otherwise 0.

\subsubsection{Control Variable}

Regarding the options for the explanation, I added the level of strong-level control and the level of the CEO. This study considers firm size, profitability, and board size as control variables. Our control variables have been received from the OSIRIS database. Control variables have been selected based on previous work (Hanifa and Cookie, 2005), which are usually proposed for these variables Gives a relationship with the expression. By controlling these variables, their effects on reliable variables are considered. Below is an explanation for the variables in each control.

Regarding the firm level, the first control variable is an index of the size of the company "total assets". A strong decision was taken firmly in many publishing studies, including CRR reporting (Hanifa \& Cookie, 2005). The larger organization can be involved in various activities and can have a more significant effect on society. They may be more likely to implement more CSR to change their public image. For the reason that firm size I used as a control variable. The size of the firm is measured in different ways: Total Assets, Operating Revenue, Market Capital, Sales and Number of Workers. But this study we performed a log transformation.

The second control variable is the Profitability which has been given by the database OSIRIS. Many previous studies of the relationship between profitability and publication were also tested (Hanifa \& Cookie, 2005), but the results are incomplete. It is advisable that profitable companies may spend more on the publication process and this gives more flexibility for managers to report their CSR activities. 
DOI: 10.14807/ijmp.v12i1.1237

However, it has been shown that the profitability of the profit is shown in the opposite sequence. The current study is measured by returning the profit of the equity company. Benefit is not used as measurable due to the period of unrest related to the annual report profit. Use of ROE is consistent with another publishing-based research (Hanifa \& Cookie, 2005).

The third and final control variable is board size. Many previous publications have published the size of the board . Both positive and negative arguments favoring the big and small size boards are previously identified. There is nothing to say that compared to the large size board, small size boards can work together with excellent communication and coordination, which makes it easy for the board to decide unanimously. On the other hand, other large boards offer a bigger board with more exceptional experience and expertise to represent richer and different standards.

In this study, the Board is measured as a total number of members. The dependent variable, independent variables, and control variables listed below:

Table 4: Variables Measurement

\begin{tabular}{|c|c|c|}
\hline Type of variable & Description & Measurement \\
\hline Dependent variable & Corporate Donation & Log transformation \\
\hline \multirow{3}{*}{ Independent variables } & CEO's Age & Log transformation (age) \\
\hline & CEO's Education & $\begin{array}{l}\text { 1. } 1 \text { if CEOs Education level Masters or above and } 0 \text { for } \\
\text { Other. } \\
\text { 2. } 1 \text { if CEOs Education Business and } 0 \text { for Other. }\end{array}$ \\
\hline & CEO's Religions & $\begin{array}{l}\text { 1. } 1 \text { if CEOs Religion is Islam and } 0 \text { for Other. } 2.1 \text { if } \\
\text { CEOs Religion is Christian and } 0 \text { for Other. } \\
\text { 3. } 1 \text { if CEOs Religion is Hindu and } 0 \text { for Other. } 4.1 \text { if the } \\
\text { CEO is no Religion and } 0 \text { for Other. }\end{array}$ \\
\hline \multirow{6}{*}{ Control variables } & Firm size & Log transformation (Total Assets) \\
\hline & Board size & Total Number of Director \\
\hline & Return on Assets (ROA) & Net income/Total assets \\
\hline & Leverage & Total Debt/Total Assets \\
\hline & Sales & Log transformation (sales) \\
\hline & Cash & Cash flow from operation/Total asset \\
\hline
\end{tabular}

\section{EMPIRICAL RESULTS}

\subsection{Descriptive statistics}

The above table shows the descriptive statistics for the dependent as well as the explanatory variables under this study. The analysis of this table concludes that the mean value of the donation is .0842 and the mean value of CEO's age is 4.0201, which is the maximum age of CEO is 4.4426 and the minimum age of CEO is 3.5263. The average member of the board in a particular company is 3, with a maximum member of the board is 4 and the minimum member of the board is 2 . The average value of particular company's return on asset is $0.1435 \%$ and the mean value of firm size is 15.4504 . The analysis of this table shows that the mean value 
INDEPENDENT JOURNAL OF MANAGEMENT \& PRODUCTION (IJM\&P)

http://www.ijmp.jor.br

v. 12, n. 1, January-February 2021

ISSN: 2236-269X

DOI: 10.14807/ijmp.v12i1.1237

of leverage is 0.5983 , which is the maximum value of leverage is 53.7910 and the minimum value of leverage is 0.0002 . The average value of a particular company's sales is 14.5220 and the mean value of cash is 0.1083 or $10.83 \%$

On the other hand, concerning stander deviation, the standard deviation of donation, cash and CEO age are $0.2430,0.2416$, and 0.2026 , which is less volatile as compared to the other variables. Whereas the highest deviation from their mean is Leverage which value is 3.4058, and the others variables deviation from mean is less as compare to the above-discussed highest and lowest value which means that these variables are the most reliable and smooth in this study.

Table 5: Descriptive statistics

\begin{tabular}{lcccc}
\hline Variable & Mean & Std. Dev. & Min & Max \\
\hline Donations & 0.0842 & 0.2430 & 0 & 1.8533 \\
Firm Size & 15.4500 & 1.9229 & 10.434 & 20.1050 \\
Board Size & 2.7106 & 0.5562 & 1.7917 & 4.1743 \\
Leverage & 0.5983 & 3.4058 & 0.0002 & 53.7910 \\
ROA & 0.1435 & 0.3154 & -0.0573 & 2.1640 \\
Sales & 14.522 & 1.4056 & 8.8648 & 18.860 \\
Cash & 0.1083 & 0.2146 & -0.0424 & 2.1182 \\
CEO Age & 4.0201 & 0.2026 & 3.5263 & 4.4426 \\
CEOs (business Education) & 0.2500 & 0.4337 & 0 & 1 \\
CEOs (Education Level) & 0.3900 & 0.4885 & 0 & 1 \\
CEOs Islam & 0.9166 & 0.2768 & 0 & 1 \\
CEOs Christian & 0.0416 & 0.2001 & 0 & 1 \\
CEOs Hindu & 0.0312 & 0.1742 & 0 & 1 \\
\hline
\end{tabular}

\subsection{Correlation Matrix}

Correlation matrix identifies the direction and strength of the relationship between all under this study variables. If the correlation between variables finds significant, it can cause the multicollinearity, which can manipulate the results of this study. Therefore, the explanatory variables of the best fit model must be free from such a problem. The base value for correlation is 0.86 and beyond his point, the multicollinearity exists. The table shows that the correlation for all explanatory variables uses this study. All the values are less than the cut point which shows that there is no multicollinearity and will not manipulate the results of the estimated model.

Table 6: Correlation matrix

\begin{tabular}{|c|c|c|c|c|c|c|c|c|c|c|c|c|c|}
\hline & & 1 & 2 & 3 & 4 & 5 & 6 & 7 & 8 & 9 & 10 & 11 & 12 \\
\hline 1 & Donations & 1 & & & & & & & & & & & \\
\hline 2 & Firm Size & $0.346^{* * *}$ & 1 & & & & & & & & & & \\
\hline 3 & Board Size & $0.326^{* * *}$ & $0.767^{* * *}$ & 1 & & & & & & & & & \\
\hline 4 & Leverage & 0.0791 & 0.0299 & -0.0950 & 1 & & & & & & & & \\
\hline 5 & ROA & $0.390^{* * *}$ & $0.579^{* * *}$ & $0.581^{* * *}$ & 0.0420 & 1 & & & & & & & \\
\hline 6 & Sales & $0.156^{*}$ & $0.602^{* * *}$ & $0.379^{* * *}$ & 0.0957 & $0.175^{* *}$ & 1 & & & & & & \\
\hline 7 & Cash & -0.0673 & $-0.304^{* * *}$ & $-0.170^{* *}$ & 0.0209 & -0.0240 & 0.107 & 1 & & & & & \\
\hline 8 & CEOs Age & 0.0340 & 0.106 & $0.208^{* * *}$ & -0.0415 & 0.0168 & 0.0799 & 0.0126 & 1 & & & & \\
\hline
\end{tabular}


ISSN: 2236-269X

DOI: 10.14807/ijmp.v12i1.1237

\begin{tabular}{l|l|l|l|l|l|l|l|l|l|l|l|l|l}
\hline & Education) & & & & & & & & & & \\
\hline 10 & $\begin{array}{l}\text { CEOs (Education } \\
\text { Level) }\end{array}$ & 0.0618 & 0.0943 & 0.108 & 0.101 & 0.0588 & $0.234^{* * *}$ & $0.206^{* *}$ & $-0.163^{* *}$ & $0.647^{* * *}$ & 1 \\
\hline 11 & CEOs Islam & -0.0364 & -0.0319 & -0.0661 & $-0.241^{* * *}$ & 0.0133 & $-0.274^{* * *}$ & -0.0789 & 0.0423 & $-0.254^{* * *}$ & $-0.233^{* * *}$ & 1 \\
\hline 12 & CEOs Christian & 0.0690 & 0.0903 & $0.182^{* *}$ & -0.0377 & 0.0156 & $0.292^{* * *}$ & 0.0917 & 0.0422 & $0.238^{* * *}$ & $0.275^{* * *}$ & $-0.689^{* * *}$ & 1 \\
\hline 13 & CEOs Hindu & 0.00272 & -0.0110 & -0.0963 & $0.431^{* * *}$ & -0.0118 & $0.126^{*}$ & 0.0398 & $-0.138^{*}$ & $0.169^{* *}$ & 0.105 & $-0.593^{* * *}$ & -0.0434 \\
\hline
\end{tabular}

\subsection{Regression analysis}

The econometric model presented the flowing results. The F-statistics and P-value of all models are significant which tell us the fitness of the model. The value of coefficient of determination R2 are $0.176,0.152,0.171$, and 0.158 respectively. It shows that all independent variable cause variation in corporate donation. The results of all model conclude that CEO's Education (Business), CEOs religion (Islam), CEO's religion (Christian) with the co-efficient values are $0.0807,0.0479$ and 0.101 .

The result shows that the education is one of the essential factors which creates the value of the particular company, this result also indicates that the CEOs business education is positive and Significant which is ultimately effect on the organization. In the organizations, the role of the CEO'S is an essential part and also its religion, so if the CEO's religion is Islam and Christian, then he will be more useful for the organization's strategy about the social welfare. The variable of CEO'S belief (Islam and Christian) is positive and statistically significant which effect of the social welfare of the company which ultimately enhances the value of the organization.

The control variable is the firm size is also a positive effect on the corporate donation but not on all the models, which means that if the size of the organization is large, then the organization will more focus on the corporate contribution as compared to the small organization. The other control variable is the return on the asset which shows the performance of the particular organizations. Therefore, this variable is positive and statistically significant. This means that if the organization performance is better than its lead to the more corporate donation which is a benefit for the organization and also the other stakeholders.

Table 7: Regression Table

\begin{tabular}{|c|c|c|c|c|}
\hline & $(1)$ & $(2)$ & (3) & (4) \\
\hline VARIABLES & $\begin{array}{l}\text { Corporate } \\
\text { Donation }\end{array}$ & $\begin{array}{l}\text { Corporate } \\
\text { Donation }\end{array}$ & $\begin{array}{l}\text { Corporate } \\
\text { Donation }\end{array}$ & $\begin{array}{l}\text { Corporate } \\
\text { Donation }\end{array}$ \\
\hline \multicolumn{5}{|l|}{ Independent Variables: } \\
\hline CEOs Age & $\begin{array}{l}0.0114 \\
(0.0435)\end{array}$ & & & \\
\hline CEOs (Education Level) & & $\begin{array}{c}0.0114 \\
(0.0287)\end{array}$ & & \\
\hline CEOs (Education Business) & & & $\begin{array}{c}0.0807^{* *} \\
(0.0319)\end{array}$ & \\
\hline
\end{tabular}


INDEPENDENT JOURNAL OF MANAGEMENT \& PRODUCTION (IJM\&P)

http://www.ijmp.jor.br

v. 12, n. 1, January-February 2021

ISSN: 2236-269X

DOI: 10.14807/ijmp.v12i1.1237

CEOs religion (Islam)

$0.0479 * * *$

$(0.0139)$

CEOs religion (Christian)

$0.101^{*}$

$(0.0611)$

CEOs religion (Hindu)

0.0232

$(0.0462)$

Control Variables:

Firm Size

\subsection{4}

0.0106

0.00976

0.0115

Board Size

$(0.0158)$

$(0.0127)$

0.0271

0.0399

$(0.0121)$

$(0.0127)$

(0.0364)

$(0.0318)$

$0.244^{* *}$

$0.201^{* *}$

$(0.0330)$

0.0463

ROA

(0.0991)

Leverage

$0.00513 * *$

(0.0932)

(0.00200)

$0.00511^{* * *}$

$0.185^{* *}$

$(0.0381)$

0.191 **

$-0.00421$

(0.00196)

(0.0857)

(0.0934)

Sales

$(0.0141)$

0.00443

$0.00406^{* *}$

$0.00590^{* * * *}$

(0.00225)

0.00530

Cash

$-0.0176$

$(0.0112)$

0.00485

$(0.0115)$

$(0.0625)$

Constant

$-0.296$

$-0.0331$

$(0.0107)$

$-0.0242$

(0.0553)

(0.189)

(0.106)

(0.0505)

(0.0532)

$-0.307^{* * *}$

$-0.363 * * *$

(0.0995)

(0.118)

R-squared

0.176

0.152

0.171

0.158

F-statistics

0.0000

6.28

Prob (F-statistics)

0.0000

0.0000

0.0000

Note1: Robust standard errors in parentheses Note2: $* * * \mathrm{p}<0.01, * * \mathrm{p}<0.05,{ }^{*} \mathrm{p}<0.1$ Firm size $=$ Log transformation, Board size $=$ Total number of directors, ROA: Probability $=$ Return on asset. Leverage $=$ Total Debt $/$ Total Assets, Sales $=$ Log transformation and Cash $=$ Cash flow from operation/Total asset.

\section{SUMMARY AND CONCLUSION}

The study observes the effect of CEO's characteristics on corporate donation practices among the public listed firms. The dependent variable in this study is corporate donation while the independent variables in this study are the CEO's personal characteristics and firm characteristics. CEO's personal characteristics consist of age, education background, and religions. On the other hand, firm features are obtained from the firm size, board size, profitability, firm leverage, sales and cash which is the agency and stakeholder theory.

Using a sample of 100 firms from the Bangladeshi listed company and more than 100 CEO's, the results show that Education is one of the essential reasons why companies make value, this result also shows that CEO business education is positive and analytically significant, which ultimately affects the organization. CEO's role in the organization is an important part and its religion, so if the CEO's belief in Islam and Christian, then he will have more impact on the organization of social welfare strategies. The variability of the CEO's religion (Islam and Christian) is positive and statistically significant, which affects the social welfare of the company, which ultimately increases the company's value.

Control variables are strong influences on corporate shapes, but not all models, which means organizations will focus more on corporate donations than small organizations if the 
DOI: 10.14807/ijmp.v12i1.1237

size of the organization is enormous. Other control variables are assassin returns that show the performance of particular companies, so this variable is positive and statistically significant. This means that if the performance of the firm is even better than corporate donations which are beneficial for the firm and other stakeholders.

Also, we found that the CEO's age irrelevant result that means it doesn't matter which level of CEO's age belongs. According to my analysis, no relation between CEO's age on corporate social responsibility. Another variable Board size, I again found that, firm board size insignificant results that mean no relationship between board size on corporate social responsibility.

There are a few limitations in this study. First, the sample used in this study is associated with publicly listed companies listed on the DSC and CSE. It will be more attractive in a comparative study of another country. In addition, the results obtained in this study are conducted based on a limited year. Therefore, the results of this study cannot be generalized. Future studies can collect information for an extended period if it needs to be more precise so that analytical results can be improved. Nonetheless, information about corporate donations was less readable in annual reports. Only a few organizations present information about the charity. It is suggested that the data collection method should not be limited to annual reports. For future research information collection methods, media and firm websites can use different media to separate from annual reports.

\section{REFERENCE}

Abdullah, W. N., \& Said, R. (2018). The Influence of Corporate Governance and Human Governance towards Corporate Financial Crime: A Conceptual Paper. In Redefining Corporate Social Responsibility (pp. 193-215). Emerald Publishing Limited.

Ali, A., Li, N., \& Zhang, W. (2015). Managers' career concerns and asymmetric disclosure of bad versus good news. Working Paper, University of Texas at Dallas.

Ali, M. M., Ibrahim, M. K., Mohammad, R., Zain, M. M., \& Alwi, M. R. (2009), Malaysia: Value Relevance of Accounting Numbers. Global Practices of Corporate Social Responsibility.

Alshareef, M. N. Z. \& Sandhu, K. (2015). Integrating Corporate Social Responsibility (CSR) into Corporate Governance Structure: The Effect of Board Diversity and Roles-A Case Study of Saudi Arabia. International Journal of Business and Management, 10(7), 1-16.

Angelidis, J., \& Ibrahim, N. (2004). An Exploratory Study of the Impact of Degree of Religiousness Upon an Individual's Corporate Social Responsiveness Orientation, Journal of Business Ethics, 51(2), 119128.

Borkowski, S. C., \& Ugras, Y. J. (1998). Business Students and Ethics: A Meta-Analysis. Journal of Business Ethics, 17, 1117-1127. 
Brammer, S., \& Millington, A. (2005). corporate reputation and philanthropy: An empirical analysis. Journal of Business Ethics, 61(1), 29-44.

Calkins, M. (2000). Recovering Religion's Prophetic Voice for Business Ethics, Journal of Business Ethics, 23, 339-352.

Campbell, J. (2007). Why would corporations behave in socially responsible ways? An institutional theory of corporate social responsibility. Academy of Management Review, 32, 946-967.

Carroll, A. B., \& Brown, J. A. (2018). Corporate social responsibility: A review of current concepts, research, and issues. In Corporate Social Responsibility (pp. 39-69). Emerald Publishing Limited.

Clarkson, P. M., Li, Y., Richardson, G. D., \& Vasvari, F. P. (2008). Revisiting the relation between environmental performance and environmental disclosure: an empirical analysis. Accounting, Organizations and Society, 33(3), 303-327.

Creswell, J. W. (2014) Research Design: qualitative, quantitative and mixed methods, $4^{\text {th }}$ Edition, Croydon: SAGE Publications Inc.

Datta, D. K., Rajagopalan, N., \& Zhang, Y. (2003). New CEO openness to change and strategic persistence: The moderating role of industry characteristics. British Journal of Management. Https://doi.org/10.1111/1467-8551.00268.

Davis, K. (1975). Business and Society: Environment and Responsibility, 3rd Edition, McGraw-Hill Book Company, NY.

Donaldson, T., \& Preston, L. E. (1995). The stakeholder theory of the corporation: Concepts, evidence, and implications. Academy of management Review, 20(1), 65-91.

Epstein, E. M. (2002). Religion and Business - The Critical Role of Religious Traditions in Management Education, Journal of Business Ethics, 38, 91-96.

Fabrizi, M., Mallin, C., \& Michelon, G. (2014). The role of CEO’s personal incentives in driving corporate social responsibility. Journal of Business Ethics, 124(2), 311-326.

Frank, B. \& Schlutz, G. (2000). Does Economics Make Citizens Corrupt? Journal of Economic Behavior and Organization, 43, 101-113.

Ge, W., \& Liu, M. (2015). Corporate social responsibility and the cost of corporate bonds. Journal of Accounting and Public Policy, 34(6), 597-624.

González-Rodríguez, M. R., Díaz-Fernández, M. C., \& Simonetti, B. (2015). The social, economic and environmental dimensions of corporate social responsibility: The role played by consumers and potential entrepreneurs. International Business Review, 24(5), 836-848.

Graafland, J., Kaptein, M. \& Mazereeuw, C. (2007). Conceptions of God, Normative Convictions, and Socially Responsible Business Conduct: An Explorative Study among Executives, Business and Society, 46, 331-369.

Gupta, A., Briscoe, F., \& Hambrick, D. C. (2017). Red, blue, and purple firms: Organizational political ideology and corporate social responsibility. Strategic Management Journal, 38, 1018-1040

Haniffa, R. M., \& Cooke, T. E, (2005). The impact of culture and governance on corporate social reporting. Journal of Accounting and Public Policy, 24(5), 391-430. DOI: https://doi.org/10.1016/j.jaccpubpol.2005.06.001. 
DOI: 10.14807/ijmp.v12i1.1237

Hambrick D. (2007). Upper Echelons theory: an update. Academy of Management Review, 32, 334-343.

Hambrick, D. C., \& Mason, P. A. (1984), Upper Echelons: The Organization as a Reflection of Its Top Managers. The Academy of Management Review, 9(2), 193-206.

Hitt, M. A., \& Tyler, B. B. (1991). Strategic decision models: Integrating different perspectives. Strategic Management Journal, 12(5), 327-351.

Inoue, Y., \& Lee, S. (2011). Effects of different dimensions of corporate social responsibility on corporate financial performance in tourism related industries. Tourism Management, 32(4), $790-804$.

Jiraporn, P., Leelalai, V., \& Tong, S. (2016). The effect of managerial ability on dividend policy: How do talented managers view dividend payouts? Applied Economics Letters, 23(12), 857-862. https://doi.org/10.1080/ 13504851.2015.1114572.

Jones, T. (1995). Instrumental Stakeholders Theory: A Synthesis of Ethics and Economics. Academy of Management Review, 20(2), 404-437.

Kang, J. (2016). Labor market evaluation versus legacy conservation: What factors determine retiring CEOs' decisions about long-term investment? Strategic Management Journal, 37, 389-405.

Kotler, P., \& Lee, N. (2005). Corporate social responsibility. Hoboken, NJ: Wiley. Lantos, G., 2002. The ethicality of altruistic corporate social responsibility. Journal of consumer marketing, 19(3), 205-230.

Kuhn, J., (1998). Emotion as well as reason: getting students beyond "Interpersonal Accountability". Journal of Business Ethics, 17, 295-308.

Lee, W. S., Sun, K. A., \& Moon, J. (2018). Application of upper echelon theory for corporate social responsibility dimensions: Evidence from the restaurant industry. Journal of Quality Assurance in Hospitality \& Tourism, 19(3), 387-414.

Loi, R., Lam, L. W., \& Chan, K. W. (2012). Coping with Job Insecurity: The Role of Procedural Justice, Ethical Leadership and Power Distance Orientation. Journal of Business Ethics. Https://doi.org/10.1007/s10551-011-1095-3.

Manner, M. H. (2010). The impact of CEO characteristics on corporate social performance. Journal of Business Ethics, 93(1), 53-72.

Matten, D., \& Moon, J. (2008). Implicit and explicit CSR: A conceptual framework for a comparative understanding of corporate social responsibility. Academy of Management Review, 33, 404-424.

Maxwell, J. (2013) Qualitative Research Design: An Interactive Approach, $3^{\text {rd }}$ Edition, and USA: SAGE Publications Inc.

McCarthy, S., Oliver, B., \& Song, S. (2017). Corporate social responsibility and CEO confidence. Journal of Banking \& Finance, 75, 280-291.

Petrenko, O. V., Aime, F., Ridge, J., \& Hill, A. (2016). Corporate social responsibility or CEO narcissism? CSR motivations and organizational performance. Strategic Management Journal, 37, 262-279.

Porter, M. E., \& Kramer, M. R. (2006). The link between competitive advantage and corporate social responsibility. Harvard business review, 84(12), 78-92. 
Quazi, A. M. (2003). Identifying the Determinants of Corporate Managers' Perceived Social Obligations. Management Decision, 41(9), 822-831.

Rivera, J. \& De Leon, P. (2005). C.E.Os. and Voluntary Environmental Performance: Costa Rica's Certification for Sustainable Tourism. Policy Science, 38, 107-127.

Shahab, Y., Ntim, C. G., Chen, Y., Ullah, F., Li, H. X., \& Ye, Z. (2019). Chief executive officer attributes, sustainable performance, environmental performance, and environmental reporting: New insights from upper echelons perspective. Business Strategy and the Environment.

Sitthipongpanich, T., \& Polsiri, P. (2015). Do CEO and board characteristics matter? A study of Thai family firms. Journal of Family Business Strategy, 6(2), 119-129.

Tang, Y., Qian, C., Chen, G., \& Shen, R. (2015). How CEO hubris affects corporate social (ir)responsibility. Strategic Management Journal, 36, 1338-1357.

Waldman, D. A., de Luque, M. S., Washburn, N., \& House, R. J. (2006). Cultural and Leadership Predictors of Corporate Social Responsibility Values of Top Management: a GLOBE Study of 15 Countries. Journal of International Business Studies, 37, 823-837.

Waldman, D. A., Siegel, D. S., \& Javidan, M. (2006). Components of CEO transformational leadership and corporate social responsibility. Journal of Management Studies, 43, 17031725.

Wan, Y., Yu, S., Huang, J., Yang, J., \& Tsai, C. (2008). Using Field Server. Automation Integration for Taiwan Country-Chicken Farm Management Using Field Server.

Weaver, G. R. \& Agle, B. R. (2002). Religiosity and Ethical Behavior in Organizations: A Symbolic Interactionist Perspective, Academy of Management Review, 27(1), 77-97.

Wowak, A. J., Mannor, M. J., Arrfelt, M., \& McNamara, G. (2016). Earthquake or glacier? How CEO charisma manifests in firm strategy over time. Strategic Management Journal, 37, 586-603.

Yin, R. K. (2009). Case Study Research: Design and Methods, $4^{\text {th }}$ Edition, USA: SAGE Publications Inc.

Yin, R. K. (2011). Qualitative Research from Start to Finish, New York: The Guilford Press.

Yuan, Y., Tian, G., Lu, L. Y., \& Yu, Y. (2017). CEO ability and corporate social responsibility. Journal of Business Ethics, 1-21. https://doi.org/10.1007/s10551-017-3622-3.

Zu, L., \& Song, L. (2009). Determinants of Managerial Values on Corporate Social Responsibility: Evidence from China. Journal of Business Ethics, 88, 105-117. 